\title{
The toxicology of heroin-related death: estimating survival times
}

Xiulu Ruan, MD, Adjunct Clinical Associate Professor of Anesthesia (Corresponding Author) Dept. of Anesthesiology, Louisiana State University Health Science Center

1542 Tulane Ave. New Orleans, LA 70112

Email:drxruan88@gmail.com

Phonetzor-583-5990

Srinivaravesiari, MD, Associate Professor of Anesthesia

Director Pain Medicine Fellowship and Neuromodulation

Department of Anesthesiology, University of Michigan Health System

Back \& ram Center, 325 E. Eisenhower Parkway, Suite 100

SPC 5721, צnn Arbor, MI 48108

Email: bivdun@med.umich.edu

Phone:73 615-7246

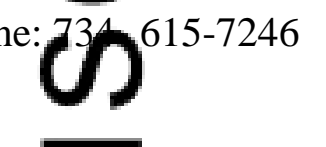

Alan D. Ka e, MD, Ph.D., Professor, Program Director, and Chairman of Anesthesia Dept. or Anesthesiology, Louisiana State University Health Science Center

1542 T arame Ave. New Orleans, LA 70112

Email:_ankaye44@ hotmail.com

Phone: 504-568-2315

Q

Word Com 504

We read with interest the article by Darke and Duflou [1] published in Addiction. Darke and s.

Duflou gramined the proportions of cases in which 6-monoacetyl morphine (6-AM) was present

in the blood, and compared concentrations of secondary metabolites and circumstances of death

by 6 . They found 6-AM was detected in $43 \%$ of cases. The median free morphine

concentration of 6-AM positive cases was more than twice that of 6-AM negative cases. 6-AM

positive cases also had lower concentrations of the other major heroin metabolites: morphine-3-

glucumi le (M3G) and morphine-6-glucuronide (M6G) with correspondingly lower

This is the author manuscript accepted for publication and has undergone full peer review but has not been through the copyediting, typesetting, pagination and proofreading process, which may lead to differences between this version and the Version of Record. Please cite this article as doi: $10.1111 /$ add.13547 
M3G/morphine and M6G/morphine ratios. Darke and Duflou conclude that in heroin-related deaths in their study sample, 6-AM was present in the blood in under half of cases, suggesting that a minority of cases had survival times after overdose of under 20-30 minutes. They believe that thentoxicology of heroin metabolites and the circumstances of death were consistent with 6AM as prof for a more rapid death [1].

-

We wotmenf any urine 6-AM was tested in those decedents who tested negative for blood 6-AM or whatperdentage of blood 6-AM positive also had positive urine 6-AM? If death occurred shortly apheroin intake, then very small or no 6-AM would be expected in the urine. If death occurred in delayed fashion, one would expect relatively high 6-AM concentration in the urine related concentrating effect of kidney [2]. The usually described window of time for 6-AM detection-in-urine is between 2 and $8 \mathrm{~h}$ after injection of heroin, because the enzymatic ( hydrolysis of heroin is limited due to the lack of esterase [2]. We wonder if the ratio of blood 6AM concertation to urine 6-AM concentration may better represent the proxy for a more rapid death? Further, urine 6-AM may help define an estimate of survival time as Darke and Duflou have acnowledged that in their 6-AM negative cases, they could not accurately predict how long sucviva times were [1].

Finary, Darke and Duflou emphasize that their toxicological data on morphine and its major metabolites_supported 6-AM as a measure of survival times, i.e., cases in which 6-AM was present had higher free morphine concentrations, and lower concentrations of M3G and M6G, than otweses. Interestingly, Carroll and colleagues [3] conducted an investigation, prompted 
by review of nine medical examiner cases that, on initial analysis 1 to 2 weeks after death, had only a trace amount or no free morphine detected in the blood but that, on re-examination 1.5 to 26 months later, found between 54 and $560 \mathrm{ng} / \mathrm{ml}$ free morphine in the reanalyzed blood specimens. They hypothesized that the hydrolases might still be active in bacterially contam antopsy specimens, despite preservation and refrigeration. Carroll et al. further
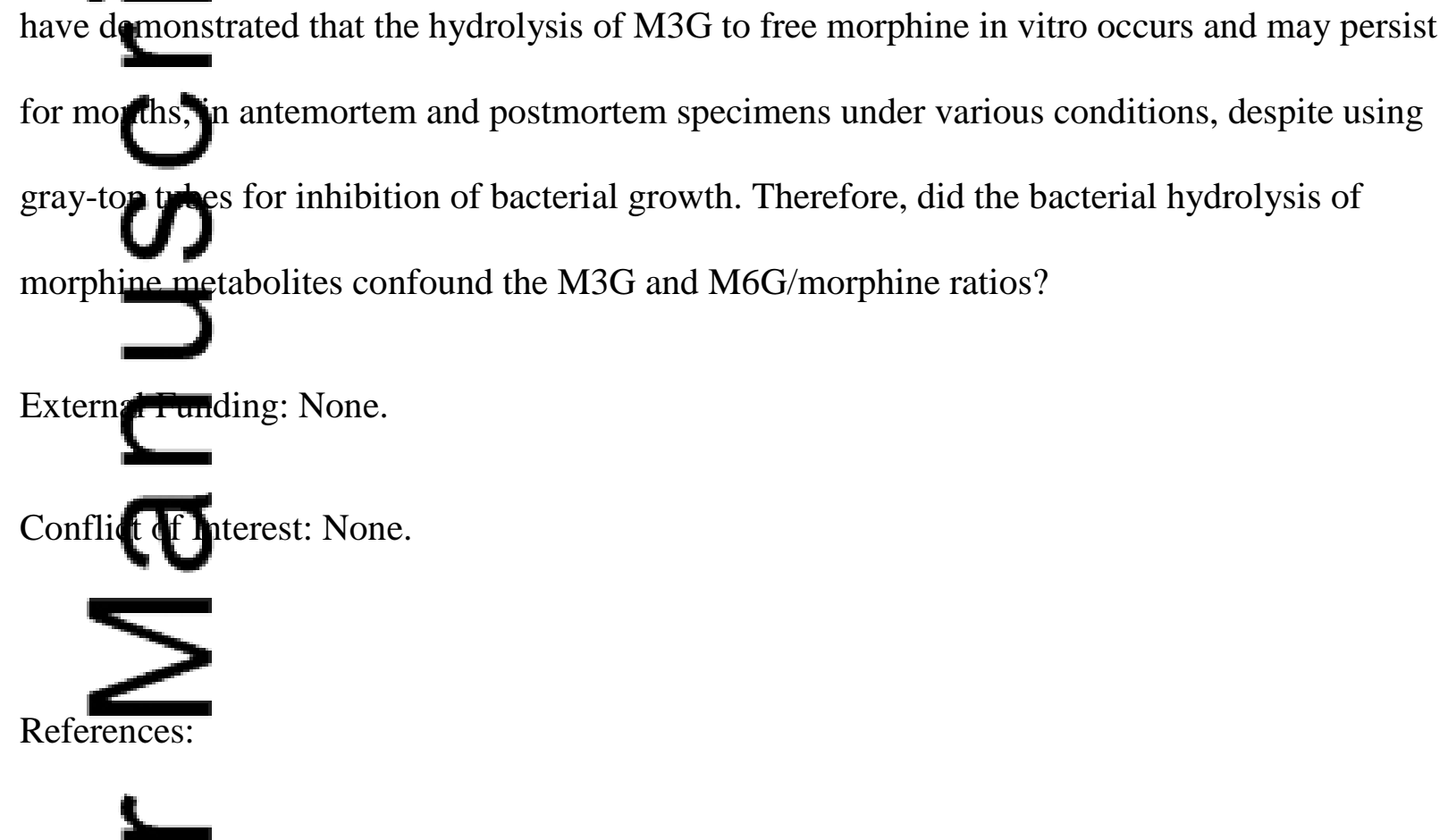

[1] S. arke J. Duflou, The toxicology of heroin-related death: estimating survival times, Adarion. (2016).

[2] F. P agor, K. Spiegel, U. Leuschner, A. Hager, Detection of 6-acetylmorphine in vitreous pumand cerebrospinal fluid-comparison with urinary analysis for proving heroin adminissration in opiate fatalities, J. Anal. Toxicol. 23 (1999) 168-172.

[3] F.T. Carroll, J.V. Marraccini, S. Lewis, W. Wright, Morphine-3-D glucuronide stability in postmo tem specimens exposed to bacterial enzymatic hydrolysis, Am. J. Forensic Med. Patnol. 21 (2000) 323-329. 


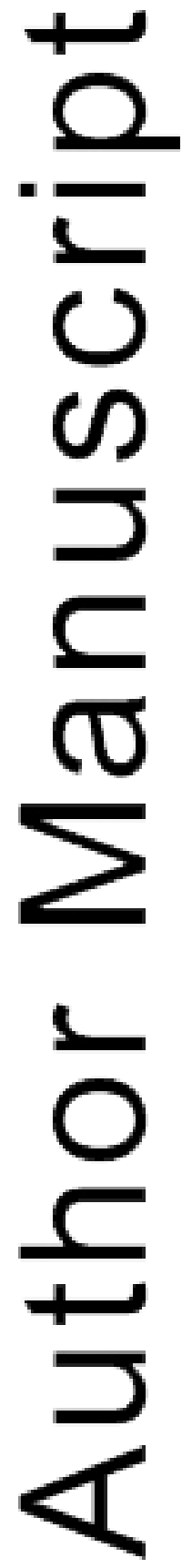

This article is protected by copyright. All rights reserved. 